\title{
FOLKLORE STUDIES AND ETHNOLOGY IN SLOVENIA 2
}

\author{
Mare Kõiva, Andres Kuperjanov
}

\begin{abstract}
The overview introduces the centres, scholars and publications of ethnology, folkloristics and visual anthropology at the Scientific Research Centre of the Slovenian Academy of Sciences. A closer look is taken to the principles of folklore collecting and publications by Karel Strekelj, founder of Slovenian folkloristics. The article introduces the research topics of modern scholars Monika Kropej, Jurij Fikfak and Naško Križnar, and Blaž Telban's ethnic art gallery Skrina.

Keywords: ethnology, folkloristics, folklore publications, Slovenia.
\end{abstract}

Absurdly long queues for kepica sladoleda, or ice-cream, in the street cafe of the sun-heated central town of Ljubljana accompany us on our morning walks to the Institute of Slovenian Ethnology, and are still there when we return late in the evening. The queues compete with the famous Ljubljana dragons and Roman ruins, and are so long that we never get to buy the icecream, which each day becomes even more mythical. We wander around in the old town, ascend to the observatory hill - a green beech grove in the outskirts of the city, where people walk their dogs and jog -, listen to an amateur choir recital in the downtown church and visit the Castle of Ljubljana built on a prehistoric settlement site.

Since the 16th century, the castle, built reportedly in the 9 th century and first mentioned in written documents in 1141, has been altered by well-known architects and used as a town prison for centuries. Since 1905, the building has been used as the cultural centre of the city, and has been under continuous reconstruction. Presently, it accommodates next to official state events, such as concerts and art exhibitions, commercial folk art facilities for tourists, and the number of tourist entertainment facilities, like cafes, etc. is constantly growing. Like in other castles in Slovenia, young couples can have a wedding with medieval clothing and show, and book special wedding rooms.

Knights and maids of honour anxiously waiting for the arrival of a bridal couple can be seen also at the castle of Predjama, near 

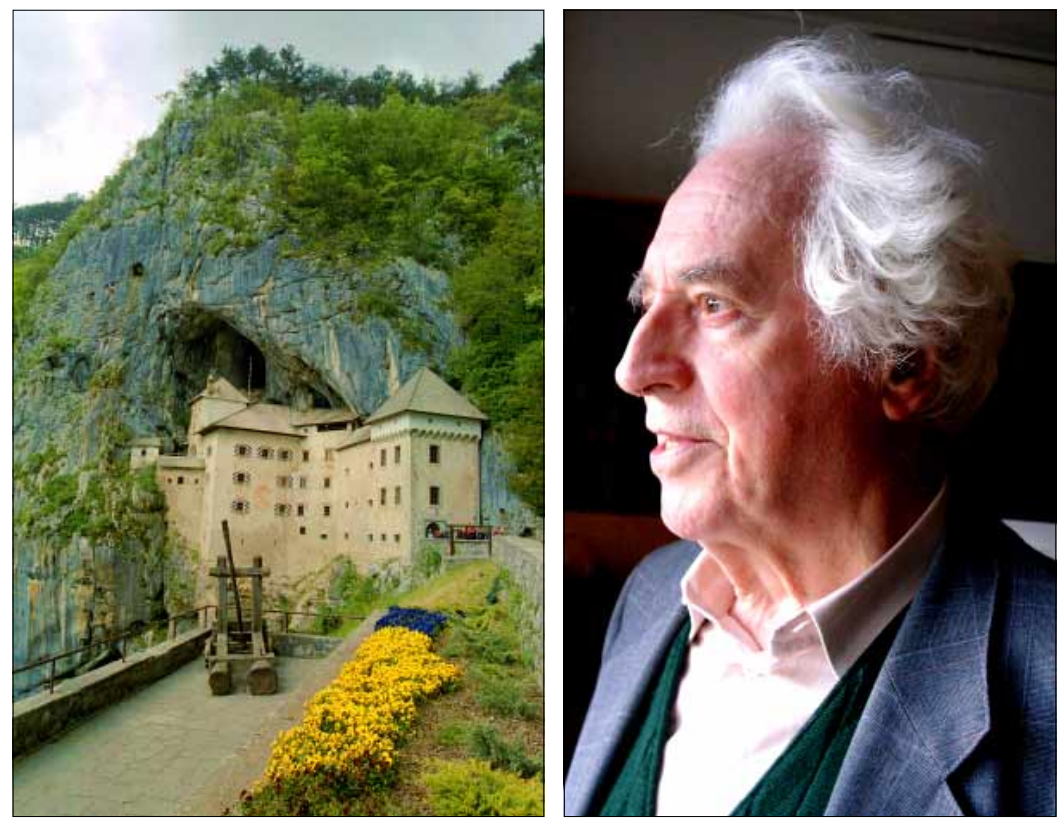

Photo 1. Predjama castle.

Photo 2. Academician Milko Matičetov.

Postojna in Slovene Karst region, which with its favourable location and numerous legends profits from staging medieval tournaments and weddings. A legend about the castle tells how the invincible fortress, which defied long sieges owing to a clever water catchment system and food obtained through secret passages, had to surrender after the enemy dropped a bomb right at the lord of the castle during his habitual contemplations in the lavatory.

The medieval marriage ceremony that we witnessed is a manifestation of the continuance of folklore, a process during which traditional rituals, calendar holidays, traditional food, clothing of a particular group, and the necessary context are being revived. Whether such staged events proceed from the need to construct and express locality, to value old traditions, or are related to the commercialisation of modern cultural values, is a separate issue. Several revived phenomena are related to the popularity of the medieval period and role play, but also to the yearning of unique life experience. Concurrently, the castle weddings play an impor- 
tant role in the recording work and analyses of contemporary folkloristics.

The history of printing in Slovenia dates back to the mid-16th century - the first printed publication originates in the year 1550 . With a touch of luck and a little help from our Slovenian colleagues, we were able to view the exhibition of the earliest manuscripts in Slovenian language, opened just for a month at the National University Library of Ljubljana. The exhibition celebrated the local literary culture by displaying authentic thousand years old manuscripts. Visitors in groups of ten are presented 9th century clerical manuscripts in a dark room of sparing lighting. The unique exhibition has been compiled from the material of Austrian, Italian, German and Slovenian collections; it is the first time in history that the manuscripts are displayed together in one room. The author of three Freising Manuscripts, which are the earliest known texts in the Slovenian language, was Bishop Abraham of Freising, whose thousandth anniversary of death was celebrated on May 26, 2004. Many valuable medieval texts and their translations are available online, as single scholars, projects and research institutions have put in a great deal of effort in the digitisation of medieval manuscripts. Frederik Kortland, professor of comparative linguistics at the Leiden University, for example, has prepared a digital publication of the Freising Manuscripts (http://www.kortlandt.nl/editions/freis.html). These earliest manuscripts, and several others in different format, style and design, displayed on the stand, which orthography and style can be observed under the instruction of the museum guide, leave a sense of exaltation and stability in the constantly changing present day; visitors who leave the exhibition are emotionally touched, while those still standing in the line are full of expectation.

The manuscript archive and specialised library of the Institute of Slovenian Ethnology is situated on the second floor, right next to the offices of scholars. A floor below is reserved for the Library of the Slovenian Academy of Sciences and Arts, which we consult for an overview in the periodicals and specialised literature of Slovenia. We mainly focus on Slovenian and West-Slavic publications, works that usually remain inaccessible for us. The library offers a good selection of German literature and that of 
the neighbouring countries. While the institutes of the Scientific Research Centre of the Academy have their own specialised libraries, an electronic interlibrary catalogue enables to order and use books held in different institutions in Slovenia. The library has a very pleasant atmosphere, which is further supported by the fact that retired ethnologists and folklorists frequent the place as often as doctoral students. Among the frequent visitors is academician Milko Matičetov, contributor to the Enzyclopädie des Märchen, who has recently taken interest in constructers of language affiliation hypotheses. $\mathrm{He}$ is also acquainted with the works and ideas of Georg Truusman. We contribute to the discussion sharing with him the ideas about affiliation with the Sumerians by Karl August Hermann and Jüri Härmatare, the theory of a possible relation with the Phoenicians by an inhabitant of Saaremaa, who has been to the GULAG and Norilsk forcedlabour prison camps, and speculations on the affiliation with the Polynesians, Basques, Ainu and other primitive nations that were prevalent in the Soviet period. Matičetov has also corresponded with the Estonian folklorist Oskar Loorits in his search for Estonian parallels to Märchen, and returned from one of his visits with the famous Estonian scholar's response, which we later managed to Xerox. Such unexpected incidents never cease to touch us.

The earlier records of the Slovenian folklore collection originate in the 19th century. The manuscripts have been systematised according to collectors and contain tradition other than folklore. The central figure in Slovenian folklore collecting is Karel Štrekelj (1859-1912), a linguist born in Gorjansko by Komen. Strekelj spent a considerable amount of his working years in Austria, where he died in 1912 as a reputed linguist, professor and expert of Slavic ethnology and folkloristics. As a linguist he was influenced by Jan Niecisùaw Ignacy Baudouin de Courtenay (1845-1929), and his longtime Slavic colleagues; as a folklorist he maintained close contacts with Jirí Georg Polívka (1858-1933) and other Slavic scholars, but was also familiar with newer German approaches. It is noteworthy that in 1887, after being elected the editor of the Slovenian folk song anthology, he founded a network of 243 contributors from all over the country. His method of collecting, as described in the monograph Karel Strekelj - iz vrelcev besedne 
ustvarjalnosti (Karel Štrekelj - From the Springs of Poetics; Ljubljana 2001) by Monika Kropej, proceeded from the wide range of historical anthropology. It took nearly eight years since the beginning of collecting until the publication of the first volume of folk songs in 1895. The four volumes published inspired a heated debate over the explicitly popular, rustic and often erotic contents of the songs. The classification and comments of the songs included in the anthology are still valid today, as are its exact registers and fully adequate paraphernalia. At the time of publication the collection received international acclaim. According to Monika Kropej, the categorisation of songs in this anthology is based on at tha time generally established system of distinguishing songs into authentic folk songs and songs that became popular. As mentioned above, Štrekelj had established close relations with the contemporary Slavic linguists, among whom he was well respected. A comparison of the leading figure of Slovenian folkloristics and the famous Estonian folklore collector Jakob Hurt (1839-1907) reveals a number of similarities and contrasts, based on the fact that both had doctor's degrees in linguistics and were ahead of their time from the modern perspective. Hurt's extensive campaigns in folklore collection and reports of material sent in by local informants proved more effective, as in the course of the campaign more than a hundred thousand pages of a wide range of materials were submitted to the Estonian Folklore Archives, and around the same time, other lore was being collected in Estonia.

Matthias Johann Eisen (1857-1934) files, which roughly originate in the same period, but are focused on other folklore genres, contain more than 90,000 pages of lore material. The anthological series of old Estonian folk songs by parishes, compiled by Jakob Hurt, is published in five copious volumes and set the standard for the tradition of taxonomy and editing of Estonian folk songs; the author's wide approach also influenced folklore collection tradition. Hurt dreamed of compiling the ethnic Estonian history on the basis of the material collected; his dream was echoed by local correspondents' attempts to find, but also to create such material.

The most distinct difference between the two scholars lies in their occupation and activities. While in the 19th century the 
Slovenian scholar worked as professor ordinary at the University of Graz, lecturing courses in Slovenian language and literature and folkloristics, and had finished translating Viennese law into Slovenian language, Jakob Hurt earned his living as a church minister. Next to the church activities and folklore collection, Hurt had to divide himself between scholarly work, meetings of the founding committee of the Estonian-language school, and numerous other activities of national movement, generation of ideas, and mind-numbing petty quarrels between the Russian-minded and German-minded members of the national movement.

The leading Slovenian scholar socialised with linguists, he relied on and shared the views of European scholars, was into palaeography, Old Church Slavic language, Serbo-Croatian literature and other interesting topics or lecture courses on related subjects. The Slovenian Historical Society, founded in 1903 on the instigation of Matija Murko (1861-1951), became, among other things, involved in ethnography. Of course, owing to the ideological situation at the time, the journal of the Historical Society was entitled Journal of History and Ethnography. Around the year of founding the society, Strekelj started his new monumental work - as the editor in chief of the anthology of Austro-Hungarian folk songs (since the 13th century, Slovenia was under the rule of the Habsburg dynasty), he began working out the compilation principles of the folk song anthology, whereat he decided to publish folk songs with tunes in musical notation. His instructions for collecting folk songs, music, dances and tradition included also technical advice for recording all the mentioned types of folklore. For additional information, he distributed a questionnaire among the local contributors. All this work, no doubt, demanded daily communication with contributors and constant effort.

The monumental anthologies of Setu folk songs by Jakob Hurt were published since 1903, though most of his plans were never materialised, just like his Slovenian colleague, who did not manage to complete the anthology of Slovenian folk tales. The two men even share outward similarities - both had the beard and moustache fashionable in the period.

During our visit to the Institute of Ethnology, we were consulted by Monika Kropej, editor of Studia mythologica Slavica. We had 


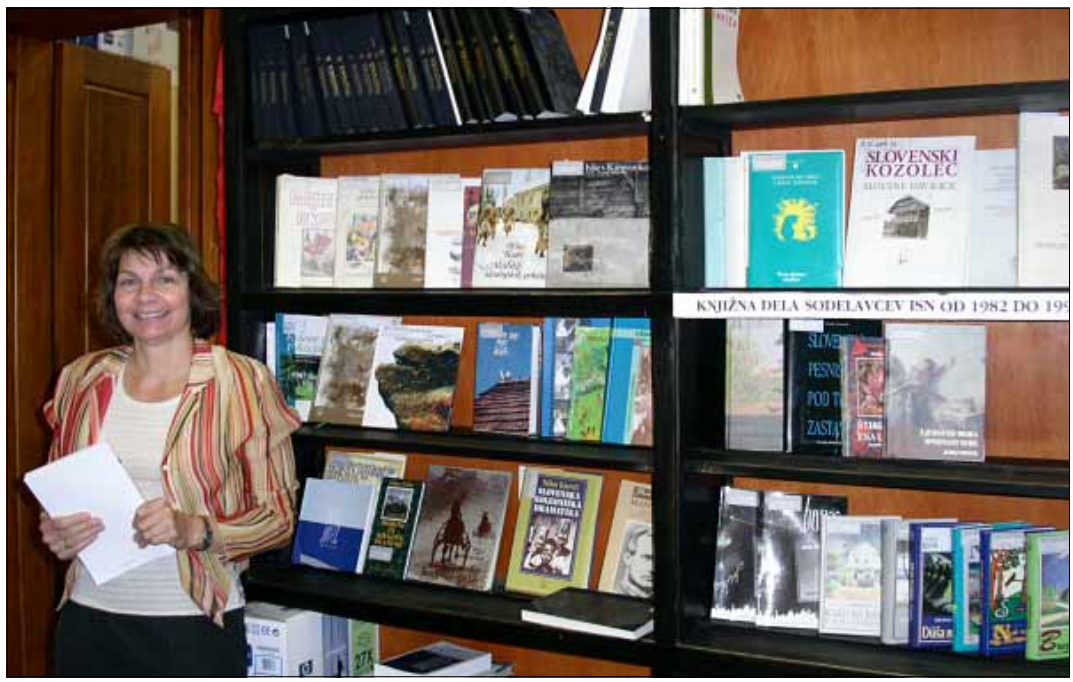

Photo 3. Monika Kropej.

met her at forums of traditional and contemporary tradition; she has successfully managed combining administrative work and journal editing with scholarly work. The 19th century folklore studies and the legacy of Karel Štrekelj is only one of her many objects of interest, as she has written about Slovenian charms (see e.g. http://www.folklore.ee/folklore/vol24/slovcharm.pdf), karst narratives, various aspects of modern and traditional narrative lore, beliefs and mythology. Her current work, the manuscript of Slovenian mythology is based on early studies on demonic creatures in folk tales. Readers interested in contemporary tales of the Slovenian students can read about them in Kropej's article (available at http://users.aber.ac.uk/mikstaff/ftn56.htm). Next to academic studies, Kropej has also edited various text anthologies, referred to previously and targeted to a wider audience.

We have also met Jurij Fikfak, another Slovenian scholar, on a number of forums over the years. On the Marseilles Congress of Société Internationale d'Ethnologie et de Folklore (SIEF), entitled Among Others in 2004, he spoke about Slovenia's accession to the EU and rituals involved with it, but also discussed several youth extremity groups. The first visit to Fikfak's office, and even 


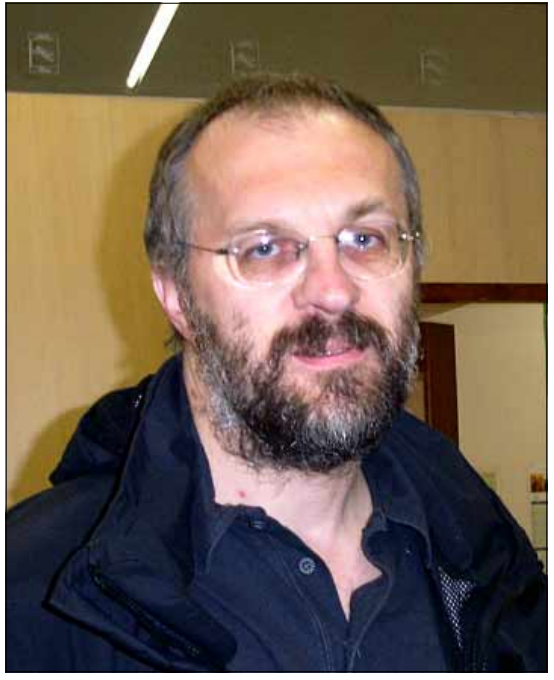

Photo 4. Jurij Fikfak. a glance at his computer screen, would make every scholar green of envy. While the Estonian folklorists had to struggle with the influences of the Soviet regime, which minimised any output, the Slovenian colleagues were influenced by the Yugoslavian period and its aftermaths. He studied at the universities of Munich and Tübingen in the mid-1980s, and in the United States at the universities in Cambridge, MA, in the mid1990 s, and used this opportunities to establish many contacts with foreign universities. Owing to his wide range of interests, he skilfully employs visual means of expression. The theoretical solutions of computer processing, databases, the use of Digital Image Processing in History (1993) and interactive means - a natural component of publications introducing specific rituals or a region - are among his interests in the area. During the past decades he has studied the reflection of ethnicity and construction of identities. In his latest publication at the Institute of Ethnography Qualitative Research: Different Perspectives, Emerging Trends (coeditors Frane Adam and Detlef Graz), he discusses the topic ranging from ethnography to autoethnography, while continuing characterising the development tendencies of folklore studies and ethnology.

In the paper he mentioned one American scholar, who presented "Eastern" scholars in the field of ethnology in the way much in common with the manner how scholars of previous centuries have characterised other nations. In the paper about Balthasar Hacquet (1739-1815), member of the European Academy of Sciences (see http://www.zrc-sazu.si/isn/Publikacije/FikfakHacquet.pdf), Jurij Fikfak, for example, has indicated how contemporary philosophy at the end of $18^{\text {th }}$ century influenced the representation of other cultures, especially those categorised as uncivilised, how 
the nations and cultural phenomena were recorded and characterised. He mainly analysed Hacquet's ethnographic descriptions of smaller ethnic groups like Slovenians, Croatians and other "savages" in Abbildung und Beschreibung der südwest- und östlichen Wenden, Illyrer und Slaven, deren geographische Ausbreitung von dem Adriatischen Meere bis an den Ponto, deren Sitten, Gebräuche, Handthierung, Gewerbe, Reiligion u. s. w. nach einer zehnjährigen Reise und vierzigjährigen Aufenthalte in jenen Gegenden. I-V. Leipzig. (1801-1808).

Slovenian ethnologists and folklorists today have joined different research networks and centres. Next to traditional folklore, their research covers currently topical subjects; the focus is also on the reinterpretation of the 19th century trends and modern schools of folkloristics. Scholars of a small nation have to take a broader perspective, much like their colleagues in the 19th century. Publications are compiled and research work are carried out in close cooperation with neighbouring fields of study and colleagues from neighbouring countries. A good example of such country-wide cooperation is a masking project, surveying the present situation of the masking tradition in the country in cooperation with ethnologists and museologists of different centres, and resulting in a publication (http://www.folklore.ee/ tagused/nr27/mare.htm), numerous documenting photographs and video recordings.

Nashko Krizhnar, head of the audiovisual centre at the Institute of Slovenian Ethnology, welcomed us on our first meeting with a question whether we have participated in the Pärnu Festival of Visual Anthropology. Once again we realised that all the participants must have shared good memories of the event.

The audiovisual centre filled with technological equipment is located a few houses off the location of the institute. Correspondents to the centre conduct regular fieldwork, some materials are processed into ethnographic documentaries for various purposes, others remain uncut, documenting certain locations and processes. Working in such a centre requires a great deal of enthusiasm and skills, as the material is rather complicated, requiring the recording of vivid images of static material with low resources. 
During our visit to the centre, a documentary about the life of destitute families during the Yugoslavian period (the 1960s) was running on VCR. The naked documentation of reality is almost identical with life in the slum apartments in Estonia. There are, certainly, also differences, which are less explicit and require further thought. Perhaps a visualisation of an archaic method of working would be useful. Returning to the topic of festivals, the centre organises a summer school for students from different European universities (hopefully we will see an Estonian student there some time in the future) and an index of filmography at the centre's homepage http://www.zrc-sazu.si/isn/avdiovizualnilab. .htm. Nashko Krizhnar has authored several articles on visual anthropology and rituals. The institution of humanities has greatly benefited from such a symbiosis of a practitioner and a theoretician; moreover, people equally skilled in research and visual arts have other advantages over a common folklorist or ethnologist. With the recording devices becoming easier to use, the number of amateur photos, documentaries and edited video recordings has increased. Having experienced a unique event, it is important to be able to record so that it would convey its extraordinariness to the audience.

The curriculum of the Chair of Ethnology and Cultural Anthropology at the University of Ljubljana is similar to that of other higher education institutions in Europe (except for its special courses in the Balkan and Slavic studies). The chair maintains academic contacts with a number of research centres, including the Max Planck Institute for Social Anthropology in Halle. The University of Ljubljana and its ethnologists have long conducted fieldwork expeditions to Africa and Eastern Europe, and researched topics ranging from punk music to traditional approaches to folklore, such as, for example, the monograph on the master of wolves, or water in Slavic mythology by Mirjam Mencej. The chair publishes monographs, articles and presentations delivered at MESS (Mediterranean Ethnological Summer School) in an academic series. As the general principle of the summer school is that scholars are allowed to speak only once, and the discussions centre on the most topical issues, the articles discuss the topics of ethnicity, cultural heritage, landscape, space, mythology, narratives, museums, etc. 


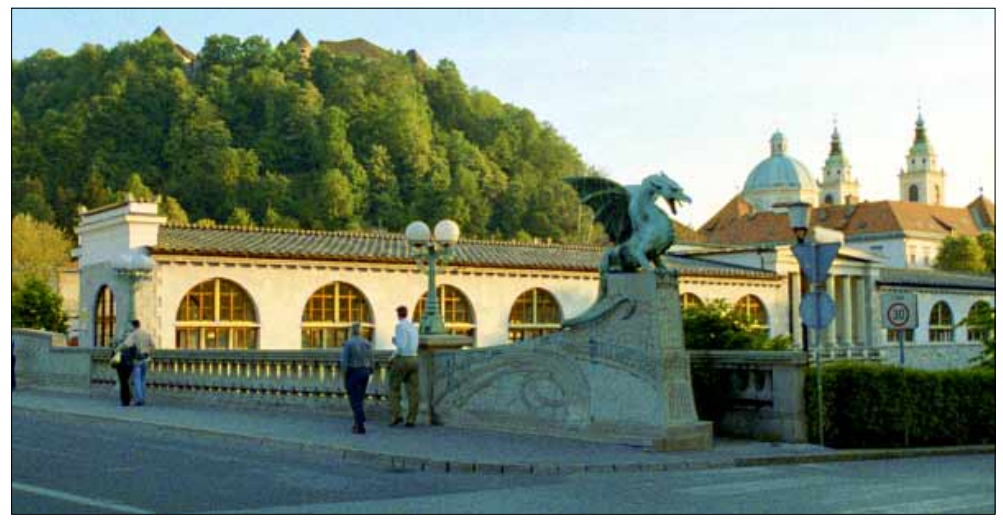

Photo 5. Dragons, found throughout the city, are the mascot of Ljubljana. The most famous of these are bridge dragons.

In addition, we were acquainted with the impressive project of digital maps and databases, useful both for scholars and in online version for the general public, of the Institute of Archaeology.

Since our arrival at the Ljubljana airport, we had noticed souvenirs of Slovenian folk art and handicraft on store windows, including humorous beehive paintings decorated with folk tale motifs or agrarian themes in warm colours. Skrina, Blazh Telban's art gallery, became the place that we recurrently visited to admire witty or simply beautiful paintings, jewellery, pottery, beehive paintings, handicraft. Blazh's gallery and personality have brought together many artists who foster ethnic style (but not only); he has established an effective system for folk art production. Being a cultural anthropologist, he has studied Native American cultures, and he wrote a book "Grupos etnicos de Colombia. Etnografia y bibliografia" (Quito in Roma 1988). After graduating from the university, he left Yugoslavia for the United States, where he worked for many years, and then returned to work in Belgrade under Miloshevich regime. In the tumultuous period preceding the overthrowing of the dictatorial regime, he could not work in his speciality and took up art. Different ethnic foods are his special interest: with his range of knowledge, he would make one of the best food anthropologists ever, the art business permitting. 


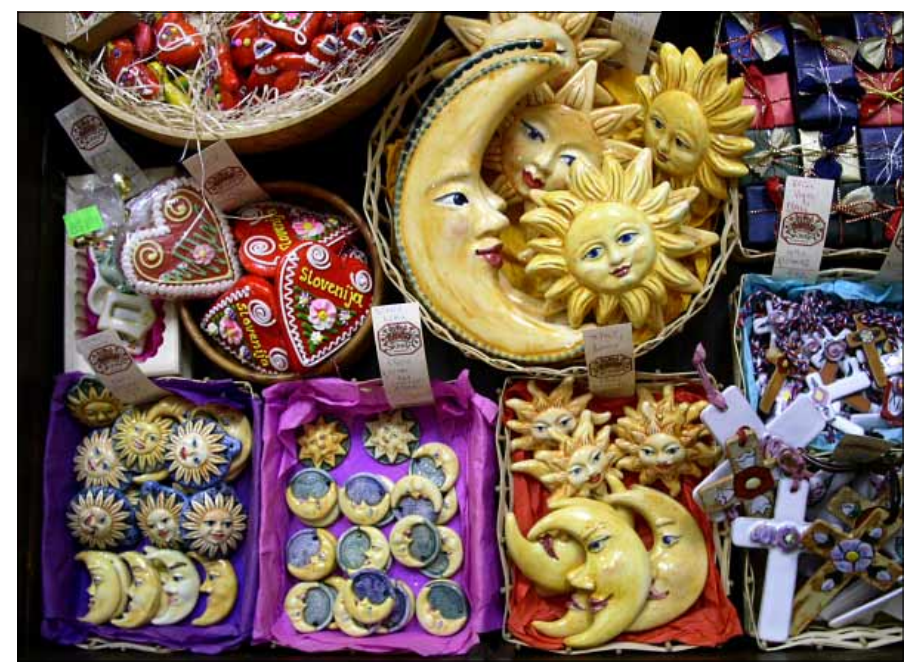

Photo 5. Ethno-gallery Skrina displays the witty, funny, serious, lucky items. Photos by Andres Kuperjanov, 2004.

Describing the atmosphere sensed while walking between the Roman walls and pillars or medieval buildings, representing a connection with infinite history, in a brief and concise manner has proved complicated. Perhaps this connection is even more strongly felt by a foreigner than by the locals. We talked to Monika Kropej about the editing and publishing of journals, comparative mythology, folklore, science politics, etc. for hours, and realised that regardless of the similarities in history, mental heritage and trends in special fields, the development of folklore studies in different countries still differs widely. The new generation of scholars in Slovenia have introduced new topics, but have continued to study the traditional genres and subjects; different research institutions have developed a unique image for themselves, characteristic topics, publications, and cooperation networks. All we can wish these institutions is continuing success in their activities. 